environmentalism. After all, a concrete parking lot is relatively stable. of Leopold's three criteria for moral rightness in the environment (beauty, stability, and integrity), only natural integrity seems to make sense. If we consider a forest that is ravaged by a fire caused by a bolt of lightning, we see a simplified system that results from a loss of stability. Moreover, it sustains a major loss of sentient life. Yet, all this is a result of natural processes, and so I see no real loss of value here. I think that this kind of case reflects the compromise criteria that Finsen is trying to develop. The key to understanding natural environmental value is not in stable environments that tend to produce $K$-selectors; the key to understanding environmental value lies in the idea of natural change.

Finally, let me say that both views, animal rights individualism and ecoholism, continue to have problems with seriously endangered species. Proponents of the former cannot say why individual rare animals are more important than plentiful ones, especially when they are ugly. Holists cannot say why non-functioning species (as most rare ones are) are important at all. I have, therefore, developed a theory (or an excuse) based on the idea of reparations. Human society owes compensation to those survivors of any extinction process begun by humans. If this view is correct, then there would be no reason to prevent naturally occurring extinctions, i.e.. extinctions that do not result from human interference in the environment. If the koala bear species eats all the leaves off the eucalyptus trees, thereby dooming both the tree species and itself, then it is simply too bad for the koala bear. They will be extinct, and humanity does not have to feel the least bit guilty.

In conclusion, let me repeat my claim that we are presented here with two different methodologies of applied ethics. The most important issue thus facing us is which approach we will take as we try to solve ethical problems regarding animals and the environment. I vote for examining the resolution of problems in the concrete situation and for postponing metaphysical speculations, however interesting they may be, because they rarely lead to pragmatic solutions.

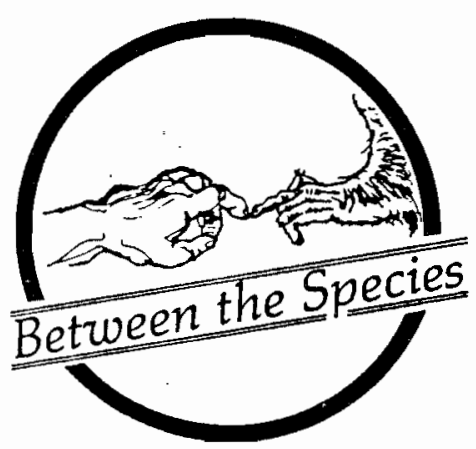

\section{ANIMAL RIGHTS}

AND ECOHOLISM

\section{ARE NOT COMPATIBLE}

\author{
SIDNEY GENDIN \\ Eastern Michigan University
}

In her admirable paper, Professor Finsen succeeds in clarifying the views of some of the leading ecoholists, and she also succeeds in showing that their views are not terribly far from those of the animal rights people. Nevertheless, there are important differences between the philosophy of ecoholism and that of animal rights that cannot be minimized. Professor Finsen is too ambitious in supposing that she can supply a theoretical reconciliation of the two positions.

I take it that the essence of Professor Finsen's paper is that those she calls ecoholists-for example, Rodman and Leopold-love not any old biotic environment but those that show "integrity, stability and beauty." These are precisely the environments that are particularly kind to the organisms that animal rights proponents favor. As she put it, the ecoholist "values the very systems which give rise to the sentient beings valued by

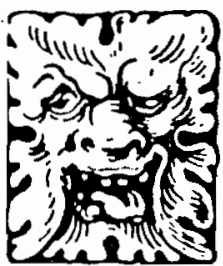

DISCUSSION 
individualists." And she makes this case out entirely persuasively. The problem, however, is that there are ecoholists and ecoholists. Whatever the stature of Rodman, Leopold, Partridge, and Sagoff, they do not have a monopoly on ecoholism and, in my opinion, do not appear, at least on the basis of Finsen's account, to present the boldest version of that philosophy.

Consider, for example, what Finsen tells us about Leopold. Leopold made the claim that a thing is good if it contributes to the integrity, stability, and beauty of the biotic community, but susan Finsen rightly points out that he did not say and in any case should not have said that a thing is good only if it makes such a contribution. In this way we can value things for reasons other than their role in the environment. Obviously she is right, and if Leopold understood this, then that is to his credit. on the other hand, there are more unbending ecoholists, such as Robert Ioftin, who explicitly claims that "it is wasteful to focus concern on animals rather than on ecosystems."[1] In Ioftin's view, no value at all

attaches, for example, to trying to give medical assistance to wild animals. And Loftin goes so far as to claim that it is only holistic entities such as species and entire ecosystems that are the locus of value. Consequently, the "only if" provision that Finsen says is lacking in Leopold is present in Ioftin. Nothing in Finsen's paper will reconcile a view such as Loftin's with a view such as Regan's.

Professor Finsen makes sensible observations about how little disagreement there need be between echolists and animal rightists over hunting and trapping, the treatment of domestic animals and the alleged paradoxes of predation, but she falters, I believe, with respect to the issue of endangered species, which is one of the irceconcilable issues separating the two camps.

Strong ecoholism (perhaps not preached by Leopold despite his near guru status in the movement), takes environments and species seriously and is not merely proposing that a more sensitive approach than is usual to the environment is for the greater good. By my saying ecoholists take environments "seriously," I mean, of course, to use this expres- sion analogously to Dworkin's use of the word when he explains what it means to take rights seriously. And what it means is that in the normal course of events, "rights trump utilities." In short, I mean that strong ecoholism is itself a rights based view. It takes species and environments seriously. I emphasize "and environments" because there are at least two other sorts of things ecoholists seem to hold dear besides species that puts them at odds with animal rights proponents.

Even if animal rights people made some grudging concessions concerning the value of species, it would nevertheless only be animal species that they could take seriously. But ecoholists appear to value plant species to about the same extent as they value animal species. I take it that the r-selection and k-selection principles that Finsen appeal to apply to plant species too, and that one can as well point to stable, beautiful plant environments with integrity as one can to animal environments. But must these k-selected environments contain the sentient beings so valued by animal rights individualists?

They need not. And certainly one can imagine a flourishing k-selected environment becoming threatened by an intruding human. Suppose Robinson Crusoe came along to a certain very small island knowing that he would be rescued in three or four months but only if he used up the otherwise self-sustaining $k$-selecting plants. This is the sort of conflict that Regan may have envisioned, and nothing in Finsen's analysis shows us how the ecoholist can be on the side of poor Mr. Crusoe.

In his review of Tom Regan's The Case for Animal Rights, [2] J. Baird Callicott confesses that Regan's liking for furry creatures "irritates" him. Callicott makes quite clear that he is not only as concerned about plants as he is with animals but also as concerned with species of plants as for species of animals. His view, though, is the very paradigm of the arcanum. He certainly doesn't grant rights to plants, since he doesn't grant them to animals; more exactly, he denies that it is sensible to attribute rights to wild animals, since that would be in effect to domesticate them (presumably a bad thing). Although he seems to think domesticated animals have some rights and wild animals do not, one must not be misled into thinking that he thinks that domesticated animals are more entitled to our concern. 
And the fact that he probably does not think that plants have rights should not lead us to suppose that he thereby thinks they are less entitled to our concern. In any case, for reasons that are too hard for me to grasp, Callicott appears to think that some mysterious ecological considerations trump both rights and ordinary utilitarian factors. Callicott appears, for whatever reason, to be more concerned about the good of, say, a weasel than he is about the good of a dachshund. In any case, however he may feel about this, Callicott does tell us that the key to reconciling environmental ethics with animal rights is to understand that wild animals have no rights. This certainly has the air of paradox, but it needn't really be a paradox. Think of it, instead, as a quaint way of telling the animal rights proponents that they are wrong. The reconciliation is a pure one way street. It is effected by asking the animal rights people to give up their view. (I must confess that I shall later make the same move of asking ecoholists to give up their view.)

Let me be very brief with respect to the other matter that I said creates an unbridgeable impasse between the ecoholists and the animal rights proponents. The other matter is the fascination the ecoholists have with non-living nature: a beautiful rock formation, the "unspoiled" wilderness, the Grand Canyon, etc. R. Will Flowers says that deep ecologists would feel repugnance at the extermination of a species of beach mouse to make room for condominiums. He likens this to murdering an old man for his life insurance.[3] I do not doubt in the slightest that Flowers (wonderful name!) would not countenance the destruction of the beach for the sake of those despised condominiums even if we could relocate the poor mouse. Ecoholists who preach this sort of love for nonliving nature are preaching, I believe, an aesthetics of nature and not an ethics. Like ecoholists, many animal respectors have a passionate love for nature's beauties, but when push comes to shove, they believe ethics takes priority over aesthetics.

I said I did not think that ecoholists are disguised consequentialists. In my view, their obsession with aesthetics confirms that. Those who worry seriously about the fate of the snaildarter understand perfectly well. I trust that the contribution of the snaildarter to the well-being of the biotic community is minimal. They must know that the world can survive the loss of the snaildarter even more easily than it has survived without the saber tooth tiger and the passenger pigeon. Despite a lot of hocum reminiscent of old Bela Lugosi movies where someone sooner or later would say, "There are things in nature man should not tamper with!," the fact is that this tampering with the snaildarter and other insignificants cannot be what bothers the ecoholist. It is, rather, that he has a deep commitment to endangered species for their own sake. He or she takes their rights seriously.

Professor Finsen proposes to reconcile the survival issue--i.e., Regan's concern over whether his life is more important than that of a wildflower--by appeal to what she calls "act holism" and "rule holism," but apart from the fact that she has the implications of these two views reversed, she cannot bring about the desired reconciliation. Finsen says that if there was some important dilemma in which one had to choose between killing a human and killing a wildflower, then rule holism (also called "indirect holism" by her) gives us a way out. It is more defensible than act-holism because it warns us not to deal with nature on a case-by-case basis. She thinks that the rule holist would advise us to sacrifice the wildflower because rule holism recognizes and respects the interests of sentient beings. However, Finsen seems to overlook the fact that an act holist can recognize the interests of sentient beings if a rule holist can. After all, their differences are methodological only and are not about fundamental values. But she characterizes the act holist as insisting that in each and every instance, we must preserve the integrity and stability of the biotic community In fact, it is only because she recognizes the inherent preposterousness of killing a human being for the sake of a wildflower that Professor Finsen is so eager to find a way out. That way is to postulate rule holism and to suppose that it would contain a rule that said something like this: whenever there is a straightforward conflict or interests such that we must choose between the survival of a human being and the survival of a wildflower, then we choose that the human being should survive. What sort of ecoholism is this? 
Any credible variety of ecoholism must contain rules that are weighted in favor of ecosystems and species. If there is such a thing as a rule holist, he or she does not propose rules for resolving conflicts between ecosystems and people; rather, she/he holds that once we discover the very best rules for maintaining the ecosystem, we should hold fast to them even when it seems that in a given circumstance we would do better for the ecosystem by violating the rule. He would not, qua ecoholist, preach that when the well-being of an ecosystem or species conflicted with the well-being of a human being, we should put the well-being of the latter ahead of the former. As for an act holist, he/she would tell us only that if we truly desire to protect the ecosystem, then it isn't good enough always to abide by rules. Whatever the internecine battles of two varieties of ecoholism, none of this will help poor Torm Regan when his life is being threatened.

When we talk of possible conflicts between a biotic community and humans, do we not usually misdescribe the nature of the conflicts? Some years ago there was the celebrated snaildarter case in which the proposed dam would have put an end to snaildarters once and for all. Note that was a real conflict. It is only philosophers who raise the issue of a snaildarter's life hanging in the balance with a human life. Environmentalists worry about strip mining and its effects on the integrity, stability, and beauty of the biotic community. They are countered with arguments concerning economic necessity or something of that sort. No one ever argues, "Either we strip mine tomorrow, or we die tomorrow." Environmentalists are usually doing battle with Secretaries of the Interior and Conmerce or representatives of the oil, mining, timber, and other industries. The conflict is not choosing between destruction of a valuable biotic system and the death of human beings. The notorious Secretary of the Interior, James Watts, did not hold the curious view that the lives of humans are being threatened by the principles of environmentalists. Nor do I think that most ecoholists want to put the well-being of the biotic community above that of the lives of the human community. That non-issue is but a red herring designed to make ecoholism look foolish. Consider how Finsen's attempt to reconcile survival dilenma depends on

BETWEEN THE SPECIES making the position of the ecoholist more palatable. I say the survival issue is a red herring because when I looked casually through some of the writings of Leopold I did not notice any discussion of what to do when a human life hung in the balance against that of a wildflower. In truth, Ieopold and his early supporters were not in the tradition of Anglo-American philosophy, thrust and counter-thrust, thesis and counter-example. This is even more obvious in the works of Leopold's predecessors, people like Audubon and John Muir, the founder of the Sierra club. Even today's environmental organizations rely heavily for their membership upon "animal lovers." The rank and file membership of groups like the Sierra Club, the National Wilderness Society, the Audubon society,

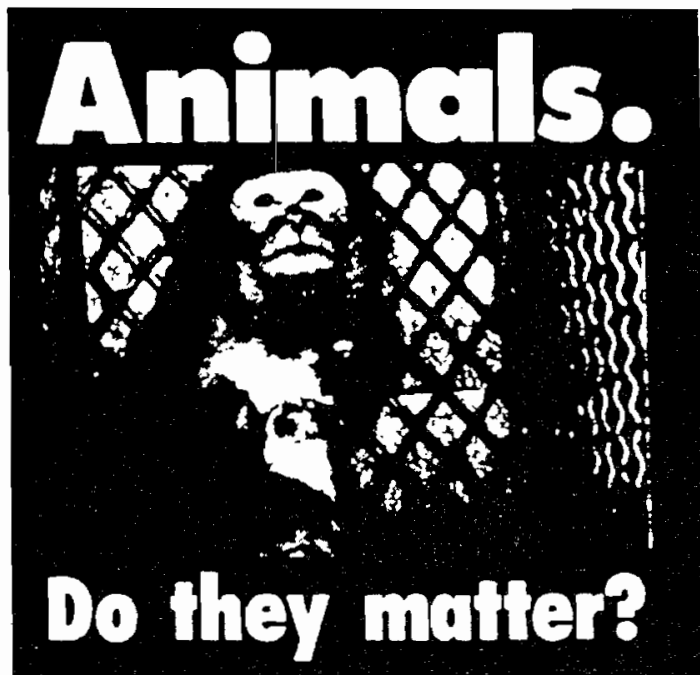

The animal rights movement is as diverse as the animals it seeks to proiect and onily one publication. The ANIMALS' AGENDA gives you comprehensive coverage of its successes. its problems. its people. and its organizations

10 issues per $y$ r. -65 pgs. and growinglt

$\square$ YES, Send mo The ANIMALS' AGENDA.

$\square 1$ yr. $\$ 18.00 \square 2$ yrs. $\$ 33.50 \square 3$ yrs. $\$ 45.00$ $\square$ Payment enclosed $\square$ Bill me

Name

Street

City State Zip

The ANIMALS' AGENDA Subscriptions P.O. Box 6809, Syracuse, NY 13217 
even, I think, Ducks Unlimited fancies itself in favor of animal rights. And perhaps the leaders of these organizations think of thenselves that way, too. What has happened is this. There is or was so much bombast on the part of those who proclaimed a "land ethic" that it was almost inevitable that there would be unrealized implications of precisely the sort that trained analytic philosophers with pro-animal sentiments were bound to take exception to. More sophisticated philosophers with pro-land ethic sentiments, like Rodman, leaped into the fray and, so far as I can tell, have extended their commitment to ecoholism beyond the wildest dreams of their original mentors. In any case, so I see it.

It is Finsen's merit that she has done her very best to salvage the views of people like Rodman by showing that they want much the same sorts of things that animal rights proponents do. Unhappily, the deck was stacked against her because--and I hope the reader won't find it outrageous that I put this so baldly--it is trivially true that sentient life has value independent of its role in any ecosystem, and it is also true, although perhaps not trivially, that an ecosystem has no value that could ever supersede the value of the totality of sentient life. (This is not to say that deep ecology is false. Ecosystems may have their own, but lesser, value independent of the value of sentient beings.) Ecoholism, when not ariven to extravagant limits, has much in it to be adnired. When it conflicts with a concern for life, it is patently absurd. The best reconciliation would be for the ecoholists to admit this.

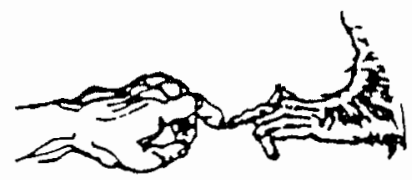

Notes

1. Robert Loftin, "The Medical Treatment of Wild Animals," Environmental Ethics (Fall, 1985).

2. J. Baird Callicott, in Environmental Ethics (Winter, 1985).

3. R. Will Flowers, "Ethics and the Hypermodern Species," Environmental Ethics (Surmer, 1986).

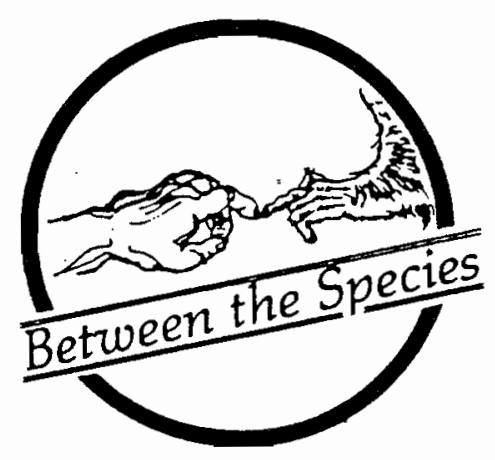

DOMBROWSKI ON

INDIVIDUALS, SPECIES,

AND ECOSYSTEMS

At the end of his excellent historical study, The Philosophy of Vegetarianism, Daniel Dombrowski suggests that "perhaps the most sophisticated version" of "a world of nature alive" "is found in the recent thought of Charles Hartshorne.[1]" The present paper develops such an Harshornian metaphysics and applies it to the moral status of individuals and species.

According to Dombrowski, animals, including humans, are individuals made up of living cells. Lacking the integration of a nervous system, plants are individuals in a much weaker sense. A mere colony of cells, "each for the most part on their own," plants also lack the psychological individuality of animals, Sentiency 2, the ability to feel pain. But lower-level feelings or experiences, Sentiency 1, exist in plants, rocks, and throughout nature at the microscopic level.

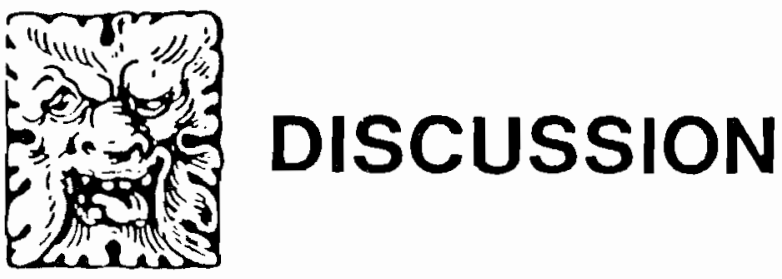

